\title{
Pemberdayaan Masyarakat Melalui Pengelolahan Hasil Pertanian Jagung Sebagai Hasil Olahan Masayarakat Kreatif Di Desa Kumba Kecamatan Jagoi Babang Kabupaten Bengkayang
}

\author{
Sumarli $^{1}$, Nurhayati ${ }^{2}$, Emi Sulistri $^{3}$, Lili Yanti ${ }^{4}$, Sri Mulyani $^{5}$, Heru Susanto ${ }^{6}$, Rini \\ Setyowati ${ }^{7}$, Rika Wahyuni ${ }^{8}$, Erdi Guna Utama9 \\ STKIP Singkawang 1,2,3,4,5,6,7,8,9 \\ sumarliphysics@gmail.com ${ }^{1}$, nurhayati@stkipsingkawang.ac.id ${ }^{2}$, sulistriemi@gmail.com³ \\ liliyantiana18@gmail.com ${ }^{4}$, srimulyani.stkip@gmail.com ${ }^{5}$, anto_heru@yahoo.co.id ${ }^{6}$, \\ rini1989setyowati@gmail.com ${ }^{7}$, rikawahyuni142@gmail.com ${ }^{8}$, \\ erdi.guna.utama@gmail.com ${ }^{9}$
}

\section{Kata Kunci :}

Pertanian, Tanaman Jagung,

Masyarakat

\begin{abstract}
ABSTRAK
Pengabdian ini mengkaji tentang kendala yang dihadapi petani dalam upaya pengembangan hasil pertanian jagung yang disebabkan oleh masyarakat yang belum mengenal teknologi pengolahan produk olahan jagung. Tujuan pengabdian ini adalah untuk mengembangkan kreativitas masyarakat dalam mengolah jagung menjadi produk olahan baru yang berdaya jual tinggi dan bernilai ekonomis. Metode yang dilakukan yaitu tahap persiapan dan pembekalan, pelaksanaan, dan rencana keberlanjutkan program. Observasi serta wawancara dilakukan guna pengumpulan informasi yang lebih konkrit. Hasil yang diperoleh yaitu terlaksananya kegiatan pengolahan jagung (Nguping) sehingga menambah pengetahuan warga akan olahan lain dari hasil pertanian jagung di Desa Kumba, Kecamatan Jagoi Babang.
\end{abstract}

\section{PENDAHULUAN}

Secara umum kondisi alam di wilayah Desa Kumba Dusun Saparan Kecamatan Jagoi Babang Kabupaten Bengkayang adalah dataran rendah. Kawasan tersebut berkarakteristik tanah bermineral berstruktur lembab, pasir, berwarna orange, kandungan air tinggi, dan didominasi lahan pertanian. Lahan pertanian terletak besebrangan dengan pemukiman warga yang di batasi oleh sungai panjang. Mayoritas warga sekitar desa adalah seorang petani dimana potensi dari hasil pertanian yaitu jagung.

Jagung adalah tanaman rerumputan tropis yang sangat adaptif terhadap perubahan iklim dan memiliki masa hidup 70-210 hari. Jagung dapat tumbuh hingga ketinggian 3 meter. Jagung memiliki nama latin Zea mays. Tidak seperti tanaman biji-bijian lain, tanamn jagung merupakan satu satunya tanaman yang bunga jantan dan betinanya terpisah (Belfield dan Brown, 2008). Jagung merupakan palawija sumber karbohidrat yang memegang peranan penting kedua setelah beras. Jagung juga mengandung unsur gizi lain yang diperlukan manusia yaitu kalori, dan protein. Dengan mengkonsumsi aneka macam produk olahan jagung, berarti telah melaksanakan program diverifikasi pangan non beras. Pengolahan jagung menjadi berbagai macam produk olahan, akan dapat meningkatkan nilai ekonomi dan nilai guna jagung sebagai bahan pangan non beras, di samping dapat meningkatkan pendapatan keluarga. Dengan 
ketersediaan jagung yang sangat melimpah tersebut, tidak memberikan dampak yang berarti bila tidak diimbangi dengan peningkatan pendapatan petani. Hal ini dikarenakan jagung akan cepat mengalami kerusakan jika tidak diberi perlakuan yang sebaik-baiknya setelah dipanen terutama jagung yang dipanen dalam usia yang masih muda. Sebagian besar produksi jagung di daerah ini hanya dijual dalam bentuk segar yang biasanya dipergunakan untuk direbus ataupun dijadikan sebagai sayuran dan sebagiannya lagi dikeringkan untuk dijadikan sebagai pakan ternak.

Secara umum masalah dan kendala utama yang dihadapi Petani Jagung di daerah Desa Kumba adalah belum adanya upaya dan pengembangan yang baik dalam usaha diverifikasi produk olahan jagung yang berdaya jual tinggi dan bernilai ekonomis. Kondisi ini dikarenakan masyarakat petani daerah ini belum mengenal teknologi pengolahan tersebut. Selain itu, minat masyarakat terhadap pangan berbasis jagung masih rendah. Hal ini disebabkan oleh kurangnya pengetahuan sebagian masyarakat tentang nilai gizi jagung, tampilan produk pangan dari jagung yang kurang menarik, dan adanya anggapan bahwa jagung hanya dikonsumsi oleh masyarakat berekonomi lemah. Maka dari itu, perlu dilakukan pengembangan usaha diverifikasi produk olahan jagung dengan keterpaduan berbagai aspek yang saling terkait satu sama lainnya, yaitu aspek produksi, aspek pengolahan, aspek pemasaran dan konsumsi. Oleh karena itulah peranan perguruan tinggi sebagai sumber tenaga ahli dan para peneliti sangat diperlukan.

\section{METODE}

Untuk mengatasi permasalahan yaitu kurang berdayanya masyarakat dalam mengolah jagung yang menjadi sasaran kegiatan. Metode pelaksanaan kegiatan KKN ini mencakup tiga tahapan yang berurutan, meliputi: (1) persiapan atau pembekalan, pada tahap persiapan dan pembekalan, langkahlangkah operasional yang dilakukan yaitu rapat koordinasi Dosen Tim Pembimbing KKN beserta jajaran pimpinan LPMPK STKIP Singkawang, menyusun laporan KKN, mengurus surat izin dari pemerintah setempat (calon lokasi KKN-PPM), pembekalan mahasiswa. (2) Pelaksanaan, pada tahap pelaksanaan kegiatan satu hari sebelum kegiatan dilaksanakan, mahasiswa melakukan observasi lokasi untuk mengidentifikasi lebih konkrit potensi, permasalahan, dan peluang masyarakat Desa Kumba Kecamatan Jagoi Babang Kabupaten Bengkayang, khususnya terkait dengan usaha mengolah jagun, kemudian melalukan wawancara: untuk pengumpulan informasi lebih konkrit potensi, permasalahan, dan peluang masyarakat Desa Kumba Kecamatan Jagoi Babang Kabupaten. (3) Rencana keberlanjutan program, untuk keberlanjutan program untuk masyarakat dapat mengembangkan program pemberdayaan yang telah dilaksanakan, mengingat bahwa terdapat potensi tinggi untuk meningkatkan perekonomian masyarakat sekitar dengan olahan tersebut atau olahan yang lainnya.

\section{HASIL DAN PEMBAHASAN}

Kegiatan KKN ini dilaksanakan di Desa Kumba Kec. Jagoi Babang. Bengkayang. Pada kegiatan pengabdian dalam pemberdayaan masyarakat dilaksanakan di Dusun Saparan, Desa Kumba. Waktu pelaksanaan 6 hari, mulai tanggal 13 Januari sampai 19 Januari 2019. Dari rencana program kerja yang disusun oleh mahasiswa STKIP Singkawang bersama dengan warga masyarakat, dalam pelaksanaannya ada beberapa kegiatan mengalami perubahan jadwal, hal ini disesuaikan dengan situasi dan kondisi di lapangan.

Meskipun demikian, secara umum dapat dikatakan bahwa kegiatan KKN-PPM yang telah dilaksanakan ini dapat dikatakan cukup berhasil. Hal tersebut ditunjukkan adanya respon positif di kalangan warga masyarakat sasaran, sehingga dengan antusias mengikuti pelatihan dan pendampingan sampai selesai. Dengan adanya kegiatan ini dirasakan sangat bermanfaat bagi peningkatan keterampilan masyarakat dalam pelaksanaan usahanya di bidang pertanian. 
Kegiatan yang dilaksanakan yaitu demo masak pembuatan puding dari jagung. Tempat dilaksanakannya kegiatan yaitu bertempat di Kantor Balai Desa Saparan. Kegiatan dihadiri oleh kurang lebih 70 orang ibu-ibu. Mahasiswa yang ikut dalam kegiatan tersebut yaitu 14 orang.
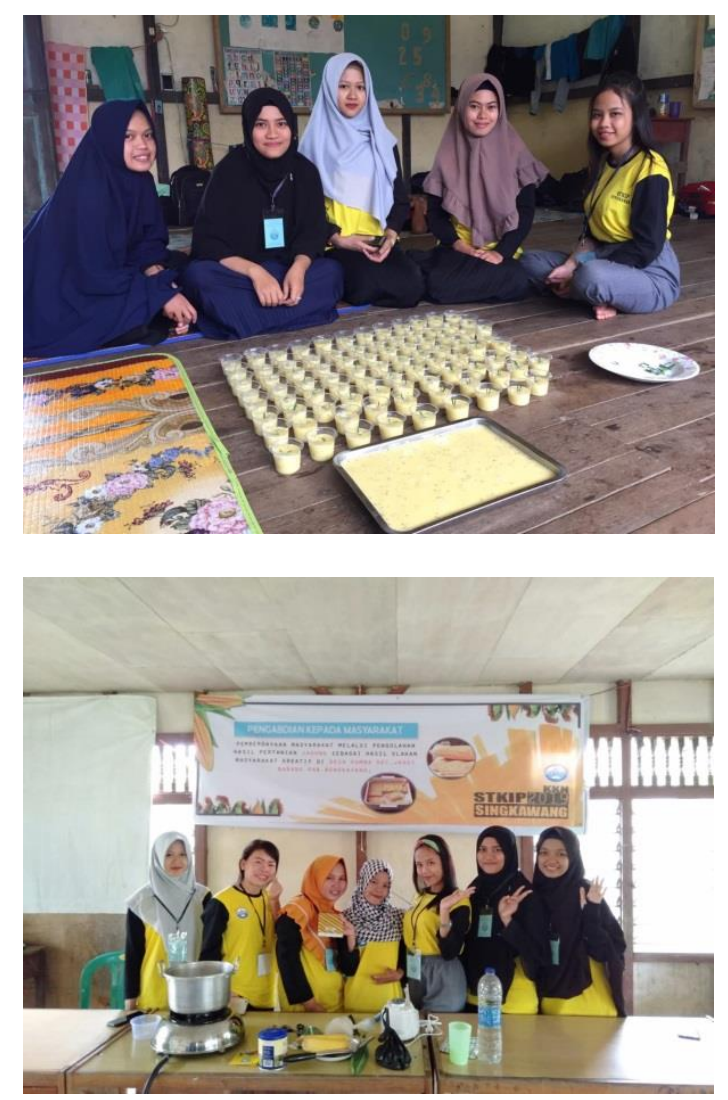

Gambar 1. Dokumentasi Pelaksanaan Kegiatan

Produk hasil olahan jagung yang telah dibuat sangat sesuai dengan yang diharapkan sebelumnya. Setelah melakukan demo masak, hasil puding yang sebelumnya telah dibuat untuk peserta sosialisasi, dibagikan masing-masing satu untuk peserta. Tanggapan ibu-ibu perserta yang ada di lokasi tersebut sangatlah positif setela mencicipi puding dari olahan jagung. Rata-rata peserta kegiatan memberikan tanggapan bahwa rasa puding yang telah diolah rasanya pas dan tidak terlalu manis, rasa jagung yang telah diolah puding juga masih terasa dominan.

Pelaksanaan NGUPING ini terlaksana dengan baik telihat dari antusias warga Desa Kumba yang ikut berpartisipasi dalam kegiatan ini. Sehingga, dengan adanya hal tersebut dapat melatih mahasiswa untuk sosialisasi dan memberikan inovasi dalam pembangunan potensi yang ada pada masyarakat.

\section{KESIMPULAN}

Kondisi alam di Wilayah Desa Kumba Dusun Saparan memiliki potensi berlimpah hasil pertanian jagung dan tentunya mayoritas penduduk tersebut bermatapencaharian sebagai petani. Warga setempat mengolah hasil pertaniannya hanya sekedar olahan pada umumnya. Masih kurangnya pengetahuan masyarakat akan inovasi lain yang dapat diolah dari hasil pertanian jagung tersebut menjadi permasalahan yang dihadapi warga sekitar, mengingat pula tekhnologi yang kurang dimanfaat oleh warga sekitar. Dengan demikian dilakukan suatu pemberdayaan masyarakat guna mengembangkan kreativitas warga untuk mengolah hasil pertanian menjadi suatu produk baru yang berdaya jual tinggi dan bernilai ekonomis seperti Jagung Puding (Nguping). Dengan adanya pemberdayaan tersebut diharapkan dapat menjadi suatu jalan atau peluang untuk warga dalam berkembang untuk meningkatkan perekonomian melalui olahan dari hasil pertanian jagung warga Desa Kumba Dusun Saparan. 
Diharapkan kepada masyarakat desa Kumba, khususnya dusun saparan tentang pengolahan jagung menjadi pudding. Maka dari itu dilakukan suatu pemberdayaan masyarakat guna mengembangkan kreativitas warga untuk mengolah hasil pertanian menjadi suatu produk baru yang berdaya jual tinggi dan bernilai ekonomis seperti Jagung menjadi olahan Puding. Namun dalam penulisan artikel ini peneliti merasa masih banyak kekurangan.

\section{UCAPAN TERIMA KASIH}

Terima kasih kepada STKIP Singkawang telah memfasilitasi dalam penyelenggaran Pengabdian Kepada Masyarakat di desa Kumba, terimakasih juga kepada Masyarakat Desa Kumba khususnya dusun Saparan yang telah menerima dengan hangat.

\section{DAFTAR PUSTAKA}

Armando YG. 2009. Peningkatan Produktivitas Jagung pada Lahan Kering Utisol Melalui Penggunaan Bokashi Serbuk Gergaji Kayu. J. Akta Agrosia 12 (2) : 124-129.

Belfield, Stephanie \& Brown, Christine. 2008. Field Crop Manual. Maize (A Guide to Upland Production in Cambodia). Canberra

Rosmaiyadi, R., Fitriyadi, S., \& Triani, S. N. (2019). Budidaya Sayur Secara Hidroponik dan Ikan Lele dengan Teknologi BioMaxi untuk Memupuk Jiwa Enterpreneurship. JPM (Jurnal Pemberdayaan Masyarakat), 4(2), 353-362.

Nuning Argo Subekti, Syafruddin, Roy Efendi, dan Sri Sunarti. 2012, Morfologi Tanaman dan Fase Pertumbuhan Jagung, Balai Penelitian Tanaman Serealia, Maros.

Sugiyono, 2004. Teknologi Pengolahan Jagung. Makalah Seminar.

Widyastuti, Yustina E. dan Adisarwanto T. 2002. Meningkatkan Produksi Jagung di Lahan Kering, Sawah, dan Pasang Surut. PT. Penebar Swadaya. Jakarta 